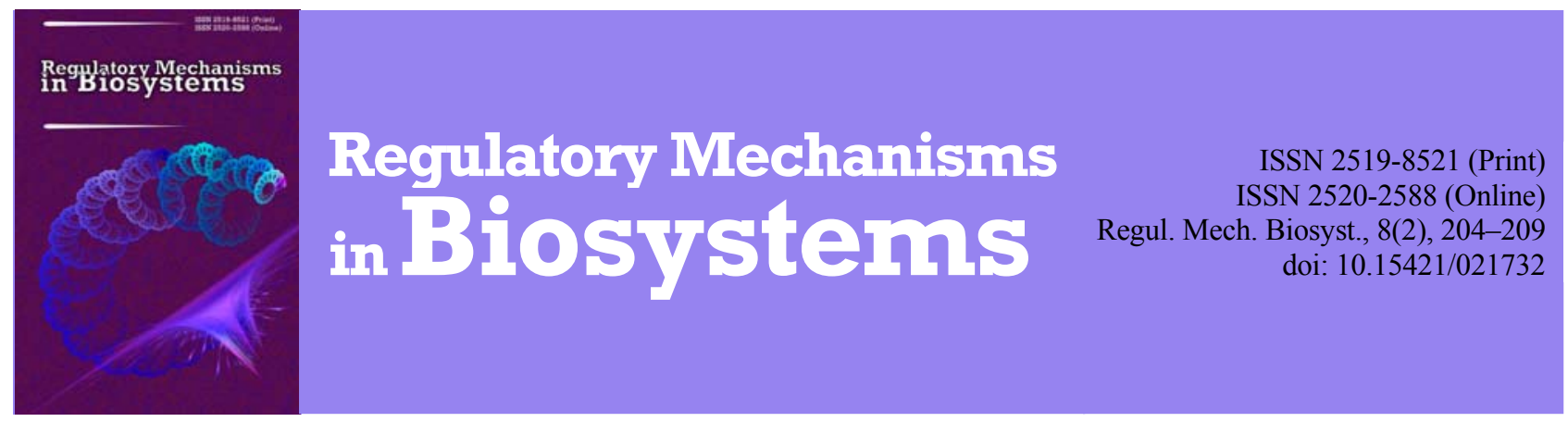

\title{
Immunohistochemical tests for diagnostics of infiltrative forms of breast cancer and identification of molecular subtype in women of different ages in Dnipro city
}

\author{
T. M. Shevchenko, P. V. Gazdyuk, A. M. Bondar, O. Y. Govoruha \\ Oles Honchar Dnipro National University, Dnipro, Ukraine
}

Article info

Received 25.03.2017

Received in revised form 28.04.2017

Accepted 05.05.2017

Oles Honchar Dnipro National University, Gagarin Ave., 72,

Dnipro, 49010, Ukraine.

Tel. $+38-056-372-58-76$

E-mail:klinlab@ua.fm

\begin{abstract}
Shevchenko, T. M., Gazdyuk, P. V., Bondar, A. M., \& Govoruha, O. Y. (2017). Immunohistochemical tests for diagnostics of infiltrative forms of breast cancer and identification of molecular subtype in women of different ages in Dnipro city. Regulatory Mechanisms in Biosystems, 8(2), 204-209. doi:10.15421/021732

The article presents the results of histological and immunohistochemical testing of women of different ages who are suffering from infiltrative forms of breast cancer in Dnipro. The study presents the distribution of receptors of estrogens and progesterone (ER, PR), HER-2/neu (necessary for prescribing treatment) and Ki-67 (reveals additional features of a tumour). Considering that luminal types of breast cancer include tumours whose receptors express to ER and PR, depending on the kind of expression HER2/neu, they are classified into A (do not express HER2/neu) and B (express HER2/neu). Tumours with hyperexpression of HER2/neu and lack of ER and PR are called HER2+. The research conducted has shown that duct cancer is by far the commonest form, at $81 \%$. In duct cancer, undifferentiated stage and moderately-differentiated stage cancer prevails, whereas with nodule cancer the majority $(80 \%)$ have moderately-differentiated stage cancer. We discovered a correlative link between the stage of differentiation and the percentage of metastasis both in duct and nodule breast cancer. But nodule breast cancer is more aggressive: with metastasis occurring in $31.2 \%$ of women even in cases of moderately-differentiated stage cancer. Only duct cancer is able to produce slime, which distinguishes it from other forms. Combined forms of cancer are rare, but they lead to metastases in all cases. Most women with infiltrative cancer in Dnipro are aged between 51 and 60 . There has been observed the increase in cases of breast cancer among young women; the most widespread among infiltrated forms of breast cancer is subtype Luminal A, which has the best prognosis. As the research shows, women under 60 tend to have less aggressive subtypes, which are easy to treat, whereas in older patients their aggressiveness increases substantially, which means an unfavourable prognosis and lower effectiveness of treatment. Ki-67 marker increases substantially in the absence of ER and PR, which means a high level of tumour aggressiveness. Luminal A subtype in not aggressive in most cases, which means the most favourable prognosis. Luminal B is partly aggressive which leads to a high percentage of metastasis, but thanks to ER+ or PR+, it is successfully treated by hormone therapy, which can lead to a positive prognosis. Overall, HER2+ and triple negative are the most aggressive.
\end{abstract}

Keywords: immunohistochemistry; breast cancer; receptor to estrogen; receptor to progesteron; marker Ki-67

\section{Імуногістохімічне дослідження для діагностики інфільтративних форм раку молочної залози та визначення молекулярного підтипу в жінок різного віку м. Дніпро}

\author{
Т. М. Шевченко, П. В. Газдюк, А. М. Бондар, О. Ю. Говоруха
}

Дніпровський національний університет імені Олеся Гончара, Дніпро, Украйна

\begin{abstract}
Наведено результати гістологічних та імуногістохімічних досліджень у хворих на інфільтративні форми раку молочної залози (РМЗ) у жінок різного віку міста Дніпро. Проаналізовано розподіл рецепторів естрогенів і прогестерону (ER, PR), HER2/nеu (необхідні для призначення лікування) і Кі-67 (розкриває додаткові властивості пухлини). Вважаючи, що до люмінальних типів РМЗ належать пухлини, рецептори яких експресують до ER та PR, залежно від експресії HER2/neu їх класифікують на А (не експресують HER2/nеu) i B (експресують HER2/neu). HER2+ називаються пухлини з гіперекспресією HER2/neu i відсутністю ER та PR. Проведені дослідження визначили, що достовірно частіше зустрічається протоковий рак (81\%). Серед протокового раку превалює рак недиференційованого та помірнодиференційованого ступеня, тоді як за долькового більша частина (80\%) має помірнодиференційований рак. Виявлено зворотний кореляційний зв'язок між ступенем диференціювання та відсотком трапляння метастазів як за протокового, так і за долькового РМЗ. Але дольковий рак агресивніший: навіть за помірнодиференційованого ступіня у $31 \%$ жінок виявленно метастази, а за недиференційованого в усіх випадках $(100 \%)$. Тільки протоковий рак здатен до слизоутворення, що відрізняє його від інших форм. Комбінований РМЗ зустрічається рідко, але в усіх випадках він метастазує. Основна частина жінок з інфільтративним раком у м. Дніпро мають вік від 51-
\end{abstract}


60 років. Відзначається збільшення кількості РМЗ серед молодих жінок, найчастіше з інфільтративних форм РМЗ виявляється підтип Luminal A, який має найліпший прогноз. У жінок до 60 років переважають менш агресивні підтипи, які добре піддаються лікуванню, тоді як у старшому віці значно збільшується їх агресивність, що говорить про поганий прогноз і гіршу ефективність лікування. Маркер Кі-67 значно збільшується за відсутності ER i PR, що говорить про високу агресивність пухлини. Підтип Luminal A у більшості випадків неагресивний, що свідчить про найліпший прогноз. Luminal B хоч і володіє невеликою агресивністю, яка говорить про більшу частоту метастазування, але завдяки ER+, i/ або PR+ добре піддається гормонотерапії, що має позитивне значення у прогнозі, тоді як HER2+ та Triple negative відзначаються найвищою агресивністю.

Ключові слова: імуногістохімія; рак молочної залози; рецептори до естрогену; рецептори до прогестерону; маркер Кі-67

\section{Вступ}

Високий рівень і темпи зростання захворюваності на РМЗ, які залишаються незмінними, зумовлюють актуальність наукових досліджень у цій галузі. На відміну від економічно розвинених країн, де РМЗ становить 26\% загальної кількості випадків захворювання на рак у жінок, і Японії, де показник дорівнює 6\%, Україна посідає проміжне місце - $18 \%$ випадків раку у жінок (Siegel et al., 2016).

Імуногістохімічне дослідження проводиться як попередній загальний скринінг, який добре зарекомендував себе в лікуванні хворих на рак молочної залози та дозволяє забезпечити максимальну ефективність лікування, уникнути при цьому невиправданих витрат.

Високий ризик розвитку РМЗ відзначають у жінок із раннім початком менструацій (до 12 років), пізньою менопаузою, народженням першої дитини у віці понад 30 років, перериванням вагітності, відсутністю пологів. У молодому та пременопаузальному віці все частіше виявляють РМЗ агресивних форм (Olopade et al., 2008; Bertos et al., 2011).

Головний вплив на розвиток РМЗ чинить зміна гормонального балансу. Частота РМЗ у жінок із підвищеним вмістом естрогену у тканинах і плазмі нижча, ніж у жінок, в яких підвищений рівень двох гормонів - естрогену та прогестерону одночасно (Fisher et al., 1989; Bardou et al., 2003; Castellano et al., 2010; Clarke et al., 2015), а в постменопаузі у плазмі крові змінюється співвідношення рівня тестостерону, андростендіону та глобуліну, що зв'язує статеві гормони (SHBG). Жінки з ознаками гіперкортицизму, гіпертонічним компонентом, хворобами печінки, віком 50-59 років і старші мають значно більший ризик розвитку РМЗ

Підвищена маса тіла та гіподинамічний спосіб життя пов'язані з розвитком резистентності до інсуліну, яка спричинює підвищення його вироблення. Потужний викид інсуліну, а також інсуліноподібного фактора росту (ILGF) сприяє підвищенню синтезу яєчниками або наднирниками статевих гормонів, зокрема андрогенів, зниженню утворення печінкою глобуліну SHBG, який зв'язує їх. У жінок у постменопаузі це зумовлює підвищення рівня естрону та, відповідно, збільшує ризик розвитку РМ3 (Loi et al., 2007; Gucalp et al., 2013).

РМЗ нерідко пов'язаний із генетичними аномаліями. Ген BRCA-1 (міститься на довгому плечі 17-ї хромосоми) бере участь в усуненні пошкоджень ДНК або знищенні клітин, в яких репарація неможлива. Його мутація зумовлює 56-87\% ризик розвитку РМЗ у віці 70 років і $33-50 \%-50$ років.

Вживання алкоголю (в тому числі в невеликій кількості) помірно підвищує ризик розвитку РМЗ, проте не виключено, що впливає i одночасний прийом гормонів або генетична схильність. Вплив куріння фахівці продовжують обговорювати, відзначаючи, що тютюн як антиестроген може чинити захисну дію. Що стосується впливу іонізуючого випромінювання, то дані тривалих спостережень за мешканками Хіросіми та Нагасакі свідчать про підвищення ризику розвитку РМЗ, особливо якщо вплив відбувся у період статевого дозрівання (Jordan, 2014).

Висунуто також вірусну теорію розвитку РМЗ. В експериментах на мишах ретровіруси викликали зміни на молочній залозі. Фіброзно-кістозна мастопатія та інші проліферативні захворювання молочних залоз підвищують ризк розвитку РМЗ.

За анатомічними ознаками виділяють:

- вузлові форми (обмежений вузол у молочній залозі);
- дифузні форми (набрякова, дифузно-інфільтративна, лімфангітична, мастотоподібна, панцерна);

- атипові форми (рак Педжета, первинно-метастатичний рак без виявленого пухлинного процесу в молочній залозі).

Згідно 3 класифікацією ВООЗ, гістологічні варіанти раку молочної залози: 1) неінфільтративний, 2) інфільтративний, 3) рак Педжета.

Гістологічне дослідження дає можливість установити наявність раку, визначити гістологічну форму (протоковий, дольковий, комбінований) та стадію диференціювання (високо-, помірно-, або недиференційований рак). Але цього недостатньо для вибору тактики та ефективності лікування, визначення прогнозу, на відміну від морфологічних підтипів, які розкривають біологічні особливості пухлини. Тому додатково проводять визначення експресії рецепторів до онкомаркерів за допомогою ІГХ. Його суть полягає у визначенні локалізації антигенів за допомогою специфічних антитіл, тобто імунологічні реакції «перенесені» на предметне скло морфолога (Isola, 1993; Nadji et al., 2005; Schnitt, 2010).

Молекулярні маркери пухлини (клітинні, тканинні, біологічні) визначаються безпосередньо у пухлинній тканині або в субклітинних фракціях (цитозоль, мембрани тощо). Вони відображають різні аспекти та рівні функціонування клітини, специфіку іiі «поведінки» та регуляції - гормональну чутливість, схильність до інвазії та метастазування (Brenton et al., 2005; Нu et al., 2006; Holm et al., 2010; Haibe-Kains et al., 2012). Основні маркери РМЗ - рецептори до естрогенів і прогестерону (ER, PR), her-2/neu i Ki-67. На основі цих маркерів визначають молекулярні підтипи РМ3 (Cheang et al., 2009).

Естрогени - група жіночих статевих гормонів, що синтезуються в організмі яєчниками та регулюють специфічні статеві функції. Прогестерон (гестаген) - основний гормон жовтого тіла, що також секретується корою наднирників. Він - попередник у біосинтезі глюкокортикоїдів. Прогестерон впливає на проліферацію мамарного епітелію, через це використовується для пояснення резистентності, що поступово розвивається, до стероїдів у міру прогресу PM3. PR синтезується у клітині за впливу естрогенів, а, отже, $€$ показником функціональної активності ER.

У нормі в епітелії молочної залози спостерігається невисока експресія ER i PR (7-30\% клітин залежно від фази циклу або гормонального фону), тоді як за пухлинної трансформації значно підвищується експресія обох маркерів, що корелює 3 гістологічним диференціюванням пухлини у відповідь на гормональну терапію (Massarweh et al., 2008; Melchor et al., 2008; Lonning, 2012).

Реакції на прогестерон і естроген вважають найпотужнішими маркерами за захворювання завдяки специфічній будові лігандів, а також способу синтеза та взаємозалежності з мРНК. За впливу на них жіночих статевих гормонів утворюється комплекс, який стимулює пухлину до розмноження. Чутливість пухлини до гормонів визначається збереженням у пухлині рецепторів, здатних сприйняти гормональний сигнал $\mathrm{i}$ транслоціювати його в ядро. $Є$ відомості про існування різних форм рецепторів до естрогенів і прогестерону: РЕ-альфа, РЕбета, РП-А і РП-В. Із присутністю РЕ-альфа у пухлинах молочної залози пов'язана чутливість до тамоксифену. Рецептори прогестерону, представлені ізоформами А і В, відіграють різні ролі у проникненні стероїдів усередину клітини. А такі препарати як тамоксифен і фарестон (група антиестрогенів) впливають саме на ці рецептори, блокуючи їх, не даючи пухлинній клітині розмножуватися. 
Вміст рецепторів естрогену та прогестерону завжди вищий у високодиференційованих пухлинах, а також у хворих, що перебувають у постменопаузі, порівняно 3 жінками репродуктивного та пременопаузального віку. У рецептор-негативних пухлинах проліферація пухлинних клітин у 10 разів активніша (Kim et al., 2012; Loi et al., 2009).

Велика частина даних базується на дослідженні рецепторів ER i PR біохімічним методом, який не дозволяє оцінити рецептори гормонів тільки у клітинах пухлини, а визначає наявність рецепторів гормонів у всьому тканинному шматочку, у тому числі у стромі та нормальних протоках молочної залози. Тоді як ІГХ дозволяє уникнути цього, оскільки досліджується тканинний зріз із візуальним забарвленням структури пухлини та локалізацій рецепторів ER i PR.

Human Epidermal growth factor Receptor 2 - фактор пухлинного росту та прогресії HER2/neu (c-erbB-2) - ген родини рецепторів епідермального чинника зростання. Він локалізується на мембранах клітин та після зв'язування з лігандами активує кінази. Крім того, експресія HER2/neu відіграє важливішу роль, ніж більшість інших факторів, у прогнозі та термінах виникнення рецидиву у хворих із метастазами в лімфовузлах (Geyer et al., 2006).

У лікарській практиці маркер HER2/neu вважають чинником несприятливого прогнозу, а його високу експресію - показником високої метастатичної здатності пухлини та можливої резистентності до лікування.

У нормі через HER2/neu рецептори організм контролює процес росту, поділу та самовідновлення здорових клітин молочної залози. Під час порушення регуляції ген c-erbB-2 виробляе занадто багато однойменних рецепторів, i після зв'язування їх із білком HER2/neu клітина отримує сигнал на неконтрольоване зростання та поділ, після чого перетворюється на ракову.

Підвищений вміст білка (p185) і ампліфікація гена c-erbB-2 iз підвищеним виробленням рецептора HER2/neu характеризує HER2 позитивний рак молочної залози. Рак молочної залози 3 нормальним вмістом гена, рецептора та білка називається HER2 негативним. HER2 позитивний рак молочної залози відрізняється агресивним перебігом, зростає та поширюється швидше, ніж HER2 негативний рак молочної залози. Іноді HER2 позитивний рак може трансформуватися в HER2 негативний (Sorlie et al., 2001; Rakha et al., 2009; Badve et al., 2011; Lehmann et al., 2011).

Маркер проліферації Кі-67 дозволяє визначити «прихований» проліферативний потенціал пухлини (швидкість поділу клітин пухлини) та дозволяє судити про ступінь злоякісності. Виявляє тільки клітини, які діляться. Позитивна реакція з Кі-67 має зворотні відносини з рецепторним статусом, передбачає променеву та хіміотерапію. Якщо Кі-67 присутній у понад 14\% пухлинних клітин, то пухлина розглядається як високоагресивна $з$ вищою ймовірністю відповіді на хіміотерапевтичне лікування. За низького рівня Кi-67 та наявності позитивних рецепторів до естрогенів і прогестерону пухлина більшою мірою відреагує на гормонотерапію. Він прямо корелює зі ступенем гістологічної злоякісності, розмірами пухлини, наявністю метастазів і має зворотні зв'язки з ER i PR. Проліферативний індекс служить незалежним прогностичним показником виникнення рецидиву, загальної та безрецидивної виживаності (Nishimura, 2010; Polyak, 2011; Prat et al., 2011, 2015).

Дослідники сперечаються про рівень Кі-67. У багатьох країнах порогове значення - 20\%. Тобто понад $20 \%$ - це агресиніші пухлини 3 високою ймовірністю метастазування, менше 20\% - менш агресивні пухлини, які рідко метастазують. Але в Україні нині залишається показник 14\%. Інколи важливий для подальшого лікування поділ на слабку проліферативну активність (до 14\%), помірну (15-30\%) та високу (понад 30\%).

Завдяки цим онкомаркерам можна поділити пухлини МЗ на молекулярні підтипи, які відрізняються між собою за прогнозом розвитку та відповіддю на медикаментозну терапію (Perou et al., 2000; Sorlie et al., 2003; Wirapati et al., 2008; Parker et al., 2009).

\section{Матеріал і методи досліджень}

Дослідження виконане у два етапи. На першому етапі виконано 246 гістологічних і 25 імуногістохімічних досліджень на базі КЗ «ДО ПАБ», відділення онкопатології. Критеріями відбору матеріалу були інфільтративні форми РМЗ (протоковий, дольковий і комбінований), яким у подальшому проводили імуногістохімічне дослідження на визначення онкомаркерів (ER, PR, HER2/neu та Ki-67). Його проводили ручним методом.

Для створення таблиці диференційних морфологічних критеріїв відібрано три нозології: протоковий, дольковий і комбінований РМЗ. У кожній групі визначено випадки метастазування та слизоутворення. Після визначення онкомаркерів РМЗ поділено на молекулярні підтипи.

Пухлини класифікували за різними ступенями диференціювання згідно з рекомендаціями C. W. Elston та I. O. Ellis, які враховують ступінь ядерного поліморфізму та кількість мітозів, що дало змогу поділити на три групи: $\mathrm{G}_{1}$ - високодиференційовані пухлини (низького ступеня злоякісності), $\mathrm{G}_{2}$ - помірнодиференційовані пухлини (помірного ступеня злоякісності), $\mathrm{G}_{3}-$ низькодиференційовані пухлини (високого ступеня злоякісності).

\section{Таблиця 1}

Імуногістохімічний фенотип молекулярних підтипів РМЗ

\begin{tabular}{|c|c|c|c|c|}
\hline \multirow{2}{*}{$\begin{array}{c}\text { Молекулярний } \\
\text { підтип } \\
\end{array}$} & \multicolumn{3}{|c|}{ Імуногістохімічний портрет } & \multirow{2}{*}{$\begin{array}{c}\text { Частота виявлення } \\
\text { у м. Дніпро, \% }\end{array}$} \\
\hline & ER & PR & HER2/neu & \\
\hline Luminal A & + & + & - & 68,0 \\
\hline Luminal B & + & + & + & 5,2 \\
\hline HER2+ & - & - & + & 10,4 \\
\hline Triple negative & - & - & - & 16,3 \\
\hline
\end{tabular}

До люмінальних відносять пухлини, рецептори яких експресують до ER та PR, і залежно від експресії HER2/neu їх класифікують на А (не експресують HER2/neu) i B (експресують Her2/neu).

Для люмінального A (luminal A) (IHC маркеры: ER/PR+, HER2-, KRT8/18+) характерні пізніший вік на момент діагнозу, високий ступінь диференціювання, частіше низький, рідше помірний і дуже рідко високий проліферативний індекс. У таких пацієнток значно знижений ризик виникнення рецидивів $\mathrm{i}$ збільшена загальна виживаність. Відмічають високу ефективність гормональної терапії (тамоксифен та інгібітори ароматази) та неоад’ювантної хіміотерапії (доксирубіцин, фторурацил, циклофосфамід).

Для люмінального В (luminal B) (IHC маркери: ER/PR+; HER+; Ki-67 > 14\%) характерні ранній вік, низьке диференціювання, великий розмір пухлини та залучення лімфовузлів. Пухлини цього типу мають значно гірший прогноз і більшу схильність до рецидивів. Вони часто не чутливі до тамоксифену та інгібіторів ароматази, але чутливі до трастузумабу. У цьому типі виділяють luminal $\mathrm{B}$ позитивний (ER+ або $\mathrm{PR}+$, HER2/neu+, Ki-67 будь-яке значення понад 14\%) i luminal B негативний (ER+ або PR+, HER2/neu-, Ki-67 високе значення). Встановлено, що люмінальні типи пов'язані 3 менш агресивним перебігом і хорошим прогнозом порівняно з HER2+ i TH PM3.

HER2+ (IHC маркери: ER-/PR-; HER2+; Ki-67 понад 14\%) називають пухлини з гіперекспресією HER $2 /$ neu та відсутністю ER тa PR. Агресивні пухлини з високим проліферативним індексом, характерне низьке диференціювання, великий розмір пухлини, залучення лімфовузлів. Ефективне ад’ювантне призначення трастузумабу, не чутливі до гормонотерапії. Висока ймовірність негативного (летального) наслідку захворювання.

Базальтоподібний або тричі-негативний (basal-like, triplenegative) (IHC маркери: ER-/PR-; HER2-; CK5/6+, EFGR (HER1)+, віментин+; c-kit+). Характерні ранній вік діагнозу, протоковий або метапластичний гістологічний тип, низьке диференціювання, високий проліферативний індекс, великий розмір пухлини, залучення лімфовузлів, ядерний плейоморфізм, некрози, стромальна лімфатична відповідь. Базальні пух- 
лини відрізняються високою агресивністю, великою ймовірністю розвитку місцевого поширення та метастатичних форм. У пацієнток із базальним РМЗ дуже погані перспективи одужання незалежно від ураження лімфовузлів. Виживання в цій групі нижче, ніж для будь-якого іншого молекулярного підтипу, включаючи HER2 позитивний. Незважаючи на гнітючий прогноз, відсутність реакції на гормонотерапію та трастузумаб, «тричі-негативні» пухлини чутливі до стандартних хіміотерапевтичних схем, включаючи антрациклін, і тих, які містять таксан. Дисфункція репаративних систем робить ракові клітини уразливими для таких агентів як препарати платини, інгібітори топоізомерази I і поліADP-рибополімераз (PARP).

Дослідження 135 гістологічних препаратів виявило інфіль- тративні форми РМЗ. Згідно з результатами достовірно частіше зустрічається протоковий рак - 81\% (P < 0,05). Серед протокового раку превалює рак недиференційованого та помірнодиференційованого ступеня, тоді як за долькового більша частина пацієнток $(80 \%)$ має помірнодиференційований рак $(\mathrm{P}<0,05)$.

Виявлено зворотний кореляційний зв'язок між ступенем диференціювання та відсотком зустрічальності метастазів як за протокового, так і за долькового РМЗ.

Дольковий рак агресивніший: навіть за помірнодиференційованого ступеня у 31,2\% жінок виявленні метастази, а за недиференційованого - в усіх випадках $(100,0 \%)$.

Комбінований РМЗ зустрічається рідко, але в усіх випадках він із метастазами (табл. 2).

Таблиця 2

Гістологічні форми (протоковий, дольковий і комбінований) раку залежно від гістологічного диференціювання

\begin{tabular}{|c|c|c|c|c|c|c|c|c|}
\hline \multirow{2}{*}{$\begin{array}{c}\text { Ступені } \\
\text { диференціювання }\end{array}$} & \multicolumn{4}{|c|}{ Протоковий, 110 жінок - 81,0\% } & \multicolumn{3}{|c|}{ Дольковий, 20 жінок - 14,8\% } & \multirow{2}{*}{$\begin{array}{l}\text { Комбінований, } \\
5 \text { жінок - 3,7\% }\end{array}$} \\
\hline & високо & помірно & слабко & $\begin{array}{c}\text { недиферен- } \\
\text { ційований }\end{array}$ & високо & помірно & $\begin{array}{c}\text { недиферен- } \\
\text { ційований }\end{array}$ & \\
\hline Кількість жінок & 2 & 45 & 11 & 52 & 1 & 16 & 3 & 5 \\
\hline Кількість жінок, \% & 1,8 & 40,9 & 10,0 & 47,2 & 5,0 & 80,0 & 15,0 & 100,0 \\
\hline Метастазування, \% & 0,0 & 4,4 & 18,2 & 26,9 & 0,0 & 31,2 & 100,0 & 100,0 \\
\hline Слизоутворення, \% & 0,0 & 2,2 & 0,0 & 7,7 & 0,0 & 0,0 & 0,0 & 0,0 \\
\hline
\end{tabular}

Високодиференційований РМЗ майже не зустрічається або виявляється випадково, оскільки немає перших ознак, а більшість людей не вважають за потрібне самостійно проходити профілактичні обстеження.

\section{Результати та їх обговорення}

Під час дослідження інфільтративних форм РМЗ у м. Дніпро виявилось, що основний пік захворювань припадає на вік 5160 років. Кількість хворих віком 41-50 років майже зрівнялась із групою віком 71-80, що говорить про збільшення частоти захворювання молодших жінок (рис. 1).

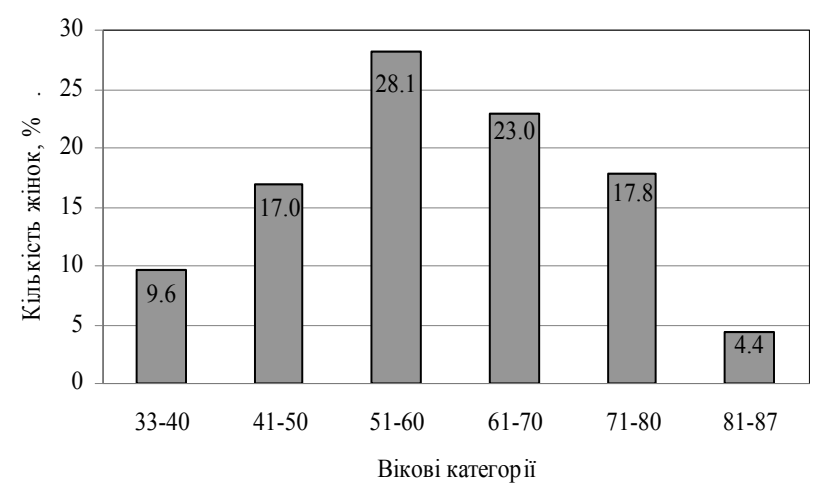

Рис. 1. Частота захворювань на РМЗ залежно від віку м. Дніпро
Після визначення онкомаркерів і поділу на молекулярні підтипи проведено ранжування, згідно з яким найчастіше виявлявся підтип Luminal A (гормонпозитивний, майже не метастазує, 3 хорошим прогнозом), далі Triple-negative (висока агресивність і здатність до метастазування, відсутність реакції на гормоно- та хіміотерапію, найгірший прогноз), HER2+ (висока метастатична здатність пухлини), та Luminal B (гормонпозитивна пухлина, яка часто метастазує, але добре лікується). Тобто у м. Дніпро найчастіше з інфільтративних форм РМЗ виявляється молекулярний підтип Luminal A, який має найліпший прогноз (рис. 2).

У жінок до 60 років переважають менш агресивні підтипи, які добре піддаються лікуванню, тоді як у старшому віці значно збільшується агресивність, що говорить про поганий прогноз розвитку захворювання та гіршу ефективність лікування.

Визначено маркер проліферації Кі-67 за різних молекулярних підтипів. Він дозволяє визначити «прихований» проліферативний потенціал пухлини (швидкість поділу клітин пухлини) та дозволяє судити про ступінь злоякісності, вірогідність метастазування. Він прямо корелює зі ступенем гістологічної злоякісності, розмірами пухлини та має зворотне взаємовідношення з ER i PR. Проліферативний індекс служить незалежним прогностичним показником виникнення рецидиву.

Якщо Кі-67 виявлено більше ніж у 14\% пухлинних клітин, такий показник вважається агресивним i більш імовірно позитивним за хіміотерапії. За значень $<14 \%$ і позитивних ER та PR, пухлина більшою мірою відреагує на гормонотерапію (табл. 3).

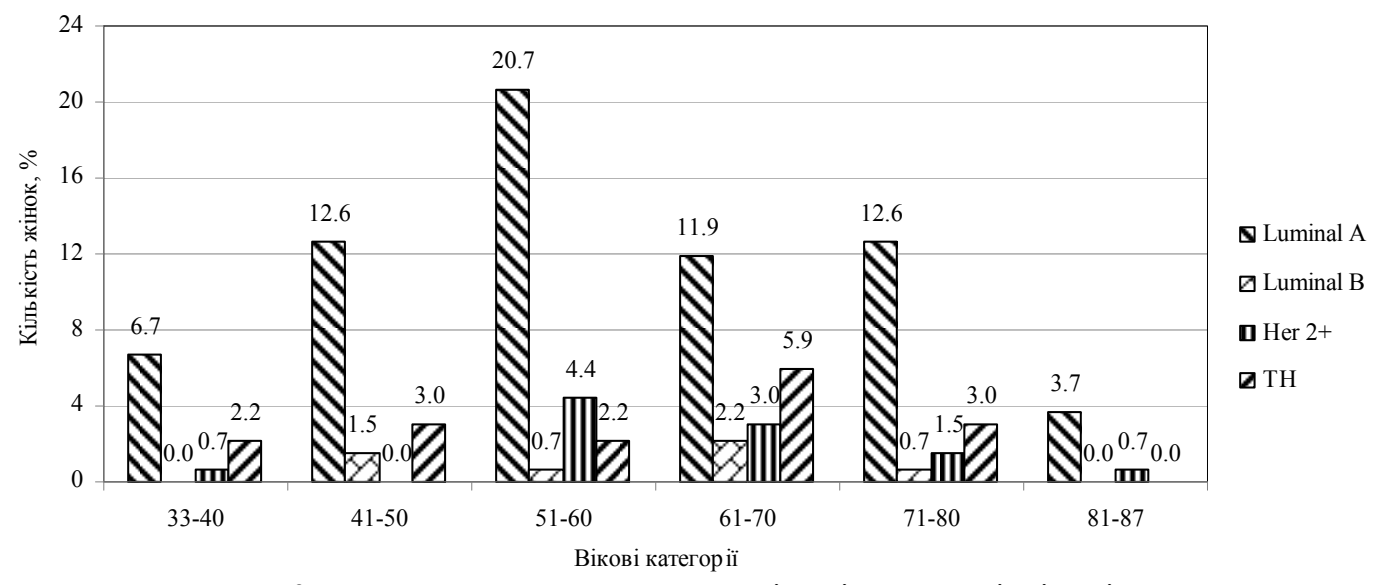

Рис. 2. Частота виявлення молекулярних підтипів залежно від віку жінок 
Таблиця 3

Показник Кі-67 залежно від морфологічних типів

\begin{tabular}{lcccc}
\multicolumn{1}{c}{ Морфологічні підтипи } & Кількість жінок, \% & Кількість жінок, абс. & Кі-67, \% & Максимальне значення, \% \\
\hline Luminal A: ER+, PR+, HER2- & & 50 & $<14$ & - \\
& 68,0 & 27 & $14-30$ & - \\
Luminal B: ER+, PR+ aбo-, HER2+ & & 15 & $>30$ & Max $=65$ \\
HER2+: ER-, PR-, HER2+ & 5,2 & 7 & $>14$ & Max $=48$ \\
Triple negative: ER-, PR-, HER2- & 10,4 & 14 & $>14$ & Max $=74$ \\
\hline
\end{tabular}

Таблиця 4

Тактика лікування залежно від молекулярного підтипу

\begin{tabular}{ll}
\hline \multicolumn{1}{c}{ Молекулярний підтип } & \multicolumn{1}{c}{ Тактика лікування } \\
\hline Luminal A: ER+, PR+, HER2- & Ефективність гормональної терапії (тамоксифен та інгібітори ароматази) та неоад’ювантної хіміотерапії \\
Luminal B: ER+, PR+ або -, HER2+ & Не чутливі до тамоксифену та інгібіторів ароматази, але чутливі до трастузумабу \\
HER2+: ER-, PR-, HER2+ & $\begin{array}{l}\text { Не чутливі до гормонотерапії, але чутливі до подальшої хіміотерапії (ад’ювантне призначення трастузумабу); } \\
\text { герцептин ефективний тільки при HER2+ PM3 }\end{array}$ \\
Triple negative: ER-, PR-, HER2- & $\begin{array}{l}\text { Відсутність реакції на гормонотерапію та трастузумаб, але чутливі до стандартних хіміотерапевтичних схем, } \\
\text { включаючи антрациклін, і тих, які містять таксан }\end{array}$ \\
\hline
\end{tabular}

Підтип Luminal A у більшості випадків неагресивний, що говорить про найліпший прогноз. Luminal B хоча і володіє невеликою агресивністю, що свідчить про більшу частоту метастазування, але завдяки $\mathrm{ER}+$ або $\mathrm{PR}+$ добре піддається гормонотерапії, що має позитивне значення у прогнозі. HER2+ та Triple negative відзначаються найвищою агресивністю (табл. 4).

Як додатковий метод для визначення молекулярного підтипу використовують FISH-діагностику.

\section{Висновки}

Серед інфільтруючих форм РМЗ більша частина - протоковий рак. Дольковий рак володіє більшою агресивністю, особливо за помірного диференціювання. Основна частина жінок м. Дніпро 3 інфільтративною формою мають вік 5160 років. Відзначається збільшення кількості РМЗ серед молодих жінок. Після визначення онкомаркерів і поділу на молекулярні підтипи проведено ранжування інфільтративних форм PM3 серед жінок м. Дніпро, згідно з яким найчастіше виявлявся підтип Luminal A, який має найліпший прогноз. Але відзначається досить велика кількість ТН, що говорить про високу агресивність пухлини, особливо в молодому віці. Підтверджено, що маркер Кі-67 прямо корелює зі ступенем гістологгічної злоякісності, має зворотне взаємовідношення з ER i PR та $є$ додатковим показником для визначення молекулярних підтипів.

\section{References}

Badve, S., Dabbs, D. J., Schnitt, S. J., Baehner, F. L., Decker, T., Eusebi, V., Fox, S. B., Ichihara, S., Jacquemier, J., Lakhani, S. R., Palacios, J., Rakha, E. A., Richardson, A. L., Schmitt, F. C., Tan, P. H., Tse, G. M., Weigelt, B., Ellis, I O., \& Reis-Filho, J. S. (2011). Basal-like and triplenegative breast cancers: a critical review with an emphasis on the implications for pathologists and oncologists. Modern Pathology, 24, 158-167.

Bardou, V. J., Arpino, G., Elledge, R. M., Osborne, C. K., \& Clark, G. M. (2003). Progesterone receptor status significantly improves outcome prediction over estrogen receptor status alone for adjuvant endocrine therapy in two large breast cancer databases. The Journal of Clinical Oncology, 2, 1974-1979.

Bertos, N. R., \& Park, M. (2011). Breast cancer - one term, many entities. The Journal of Clinical Investigation, 121, 3788-3796.

Brenton, J. D., Carey, L. A., Ahmed, A. A., \& Caldas, C. (2005). Molecular classification and molecular forecasting of breast cancer: Ready for clinical application. Clinical Oncology, 23, 7350-7359.

Castellano, I., Allia, E., Accortanzo, V., Vandone, A. M., Chiusa, L., Arisio, R., Durando, A., Donadio, M., Bussolati, G., Coates, A. S., Viale, G., \& Sapino, A. (2010). Androgen receptor expression is a significant prognostic factor in estrogen receptor positive breast cancers. Breast Cancer Research and Treatment, 124(3), 607-616.

Cheang, M. C., Chia, S. K., Voduc, D., Gao, D., Leung, S., Snider, J., Watson, M., Davies, S., Bernard, P. S., Parker, J. S., Perou, C. M., Ellis, M. J., \& Nielsen, T. O. (2009). Ki-67 index, HER2 status, and prognosis of patients with luminal B breast cancer. The Journal of the National Cancer Institute, 101(10), 737-750.

Clarke, R., Tyson, J. J., \& Dixon, J. M. (2015). Endocrine resistance in breast cancer - an overview and update. Molecular and Cellular Endocrinology, 418, 221-234.

Fisher, B., Costantino, J., Redmond, C., Poisson, R., Bowman, D., Couture, J., Dimitrov, N. V., Wolmark, N., Wickerham, D. L., \& Fisher, E. R. (1989). A randomized clinical trial evaluating tamoxifen in the treatment of patients with node-negative breast cancer who have estrogen-receptor-positive tumors. The New England Journal of Medicine, 320, 480-784.

Geyer, C. E., Forster, J., Lindquist, D., Chan, S., Romieu, C. G., Pienkowski, T., Jagiello-Gruszfeld, A., Crown, J., Chan, A., Kaufman, B., Skarlos, D., Campone, M., Davidson, N., Berger, M., Oliva, C., Rubin, S. D., Stein, S., \& Cameron, D. (2006). Lapatinib plus capecitabine for HER2positive advanced breast cancer. The New England Journal of Medicine, 355, 2735-2742.

Gucalp, A., Isakoff, S. J., Tolaney, S. M., \& Traina, T. A. (2013). Phase II trial of bicalutamide in patients with androgen receptor-positive, estrogen receptor-negative metastatic breast cancer. Clinical Cancer Research, 19, 5506-5511.

Haibe-Kains, B., Desmedt, C., Loi, S., Culhane, A. C., Bontempi, G., Quackenbush, J., \& Sotiriou, C. (2012). A three-gene model to robustly identify breast cancer molecular subtypes. The Journal of the National Cancer Institute, 104, 312-324.

Holm, K., Hegardt, C., Staaf, J., Vallon-Christersson, J., Jönsson, G., Olsson, H., Borg, A.,\& Ringnér, M. (2010). Molecular subtypes of breast cancer are associated with characteristic DNA methylation patterns. Breast Cancer Research, 12(3), 36.

Hu, Z., Fan, C., Oh, D. S., Marron, J. S., He, X., Qaqish, B. F., Livasy, C., Carey, L. A., Reynolds, E., Dressler, L., Nobel, A., Parker, J., Ewend, M. G., Sawyer, L.R., Wu, J., Liu, Y., Nanda, R., Tretiakova, M., Orrico, R. A. Dreher, D., Palazzo, J. P., Perreard, L., Nelson, E., Mone, M., Hansen, H., Mullins, M., Quackenbush, J. F., Ellis, M. J., Olopade, O. I., Bernard, P. S., \& Perou, C. M. (2006). The molecular portraits of breast tumors are conserved across microarray platforms. BMC Genomics, 7, 96.

Isola, J. J. (1993). Immunohistochemical demonstration of androgen receptor in breast cancer and its relationship to other prognostic factors. The Journal of Pathology, 170(1), 32-35.

Jordan, V. C. (2014). Tamoxifen as the first targeted long-term adjuvant therapy for breast cancer. Endocrine-Related Cancer, 21, 236-245.

Kim, H. S., Park, I., Cho, H. J., Gwak, G., Yang, K., Bae, B. N., Kim, K. W., Han, S., Kim, H. J., \& Kim, Y. D. (2012). Analysis of the potent prognostic factors in luminal-type breast cancer. Journal Breast Cancer, 15, 402-405.

Lehmann, B. D., Bauer, J. A., Chen, X., Sanders, M. E., Chakravarthy, A. B., Shyr, Y., \& Pietenpol, J. A. (2011). Identification of human triple-negative breast cancer subtypes and preclinical models for selection of targeted therapies. The Journal of Clinical Investigation, $121,2751-2766$.

Loi, S., Piccart, M., \& Sotiriou, C. (2007). The use of gene-expression profiling to better understand the clinical heterogeneity of estrogen receptor positive breast cancers and tamoxifen response. Critical Reviews in Oncology/Hematology, 61, 188-193.

Loi, S., Sotiriou, C., Haibe-Kains, B., Lallemand, F., Conus, N. M., Piccart, M. J., Speed, T. P., \& Mc Arthur, G. A. (2009). Gene expression 
profiling identifies activated growth factor signaling in poor prognosis (Luminal-B) estrogen receptor positive breast cancer. BMC Medical Genomics, 2, 37.

Lonning, P. E. (2012). Poor-prognosis estrogen receptor-positive disease: Present and future clinical solutions. Therapeutic Advances in Medical Oncology, 4, 128-136.

Massarweh, S., Osborne, C. K., Creighton, C. J., Qin, L., Tsimelzon, A., Huang, S., Weiss, H., Rimawi, M., \& Schif, R. (2008). Tamoxifen resistance in breast tumors is driven by growth factor receptor signaling with repression of classic estrogen receptor genomic function. Cancer Research, 68(3), 827-832.

Melchor, L., \& Benítez, J. (2008). An integrative hypothesis about the origin and development of sporadic and familial breast cancer subtypes. Carcinogenesis, 29(8), 1476-1481.

Nadji, M., Gomez-Fernandez, C., Ganjei-Azar, P., \& Morales, A. R. (2005). Immunohistochemistry of estrogen and progesterone receptors reconsidered: experience with 5,993 breast cancers. American Journal of Clinical Pathology, 123, 22-26.

Nishimura, R., Osako, T., Okumura, Y., Hayashi, M., Toyozumi, Y., \& Arima, N. (2010). Ki-67 as a prognostic marker according to breast cancer subtype and a predictor of recurrence time in primary breast cancer. Expernal and Therapeutic Medicine, 1(5), 748-755.

Olopade, O. I., Grushko, T. A., Nanda, R., \& Huo, D. (2008). Advances in breast cancer: Pathways to personalized medicine. Clinical Cancer Research, 14, 7987-7998.

Parker, J. S., Mullins, M., Cheang, M. U., Leung, S., Voduc, D., Vickery, T., Davies, S., Fauron, C., He, X., Hu, Z., Quackenbush, J. F., Stijleman, I. J., Palazzo, J., Marron, J. S., Nobel, A. N., Mardis, E., Nielsen, T. O., Ellis, M. J., Perou, C. M., \& Bernard, P. S. (2009). Supervised risk predictor of breast cancer based on intrinsic subtypes. Journal of Clinical Oncology, 27, 1161-1166.

Perou, C. M., Sorlie, T., Eisen, M. B., van de Rijn, M., Jeffrey, S. S., Rees, C. A., Pollack, J. R., Ross, D. T., Johnsen, H., Akslen, L. A., Fluge, O., Pergamenschikov, A., Williams, C., Zhu, S. X., Lonning, P. E., Borresen-Dale, A. L., Brown, P. O., \& Botstein, D. (2000). Molecular portraits of human breast tumours. Nature, 406, 748-751.
Polyak, K. (2011). Heterogeneity in breast cancer. The Journal of Clinical Investigation, 121, 3787-3788.

Prat, A., \& Perou, C. M. (2011). Deconstructing the molecular portraits of breast cancer. Molecular Oncology, 5, 6-21.

Prat, A., Pineda, E., Adamo, B., Galván, P., Fernández, A., Gaba, L., Díez, M., Viladot, M., Arance, A., \& Muñoz, M. (2015). Clinical implications of the intrinsic molecular subtypes of breast cancer. The Breast, 24, 25-34.

Rakha, E. A., Elsheikh, S. E., Aleskandarany, M. A., Habashi, H. O., Green, A. R., Powe, D. G., El-Sayed, M. E., Benhasouna, A., Brunet, J. S., Akslen, L. A., Evans, A. J., Blamey, R., Reis-Filho, J. S., Foulkes, W. D., \& Ellis, I. O. (2009). Triple-negative breast cancer: Distinguishing between basal and nonbasal subtypes. Clinical Cancer Research, 15, 2301-2309.

Schnitt, S. J. (2010). Classification and prognosis of invasive breast cancer: From morphology to molecular taxonomy. Modern Pathology, 23, 61-64.

Siegel, R. L., Miller, K. D., \& Jemal, A. (2016). Cancer statistics, 2016. CA: A Cancer Journal for Clinicans, 66(1), 7-30.

Sorlie, T., Perou, C. M., Tibshirani, R., Aas, T., Geisler, S., Johnsen, H., Hastie, T., Eisen, M. B., Van de Rijn, M., Jeffrey, S. S., Thorsen, T., Quist, H., Matese, J. C., Brown, P. O., Botstein. D., Lonning, P. E., \& BorresenDale, A. L. (2001). Gene expression patterns of breast carcinomas distinguish tumor subclasses with clinical implications. Proceeding of the National Academy of Sciences of the USA, 98, 10868-10873.

Sorlie, T., Tibshirani, R., Parker, J., Hastie, T., Marron, J. S., Nobel, A., Deng, S., Johnsen, H., Pesich, R., Geisler, S., Demeter, J., Perou, C. M., Lonning, P., Brown, P. O., Borresen-Dale, A., \& Botstein, D. (2003). Repeated observation of breast tumor subtypes in independent gene expression data sets. Proceeding of the National Academy of Sciences of the USA, 100, 8419-8422.

Wirapati, P., Sotiriou, C., Kunkel, S., Farmer, P., Pradervand, S., HaibeKains, B., Desmedt, C., Ignatiadis, M., Sengstag, T., Schütz, F., Goldstein, D. R., Piccart, M., \& Delorenzi, M. (2008). Meta-analysis of gene expression profiles in breast cancer: Toward a unified understanding of breast cancer subtyping and prognosis signatures. Breast Cancer Research, 10, 65. 